\title{
ASSERTION OF A JOURNALIST'S PRIVILEGE IN CONFLICT WITH THE FINAL JUDGIMENT RULE IN CIVIL LITIGATION: GIALDE v. TIME, INC.
}

In Gialde v. Time, Inc., ${ }^{1}$ the Court of Appeals for the Eighth Circuit held that a pre-trial discovery order requiring a newsinan in a suit for libel and invasion of privacy to reveal his secret sources was not a final judgment and hence was not immediately appealable under section 1291 of the Judiciary and Judicial Procedure Act. ${ }^{2}$ The court further ruled in the companion case of Time, Inc. v. Oliver ${ }^{3}$ that the situation was not suitable for the issuance of a writ of mandamus under section 1651 of the same act ${ }^{4}$ prohibiting enforcement of the pre-trial discovery order. Gialde's case was based on a photograph which appeared in the June 12, 1970 issue of defendant Time, Inc.'s Life Magazine. The picture showed a golfing group composed of Gialde and seventeen other people over a caption which read ". . . four of Kansas City's leading Mafiosi and their golfing associates." Gialde sued Time both for invasion of privacy ${ }^{6}$ and for libel. During pre-trial discovery, Life investigator Denny Walsh refused to reveal both the name of the government agent who had given him information regarding the identity of the persons in the photograph and the name of the government agency which employed this agent. Walsh argued

1. 480 F.2d 1295 (8th Cir. 1973).

2. "The court of appeals shall have jurisdiction of appeals from all final decisions of the district courts of the United States . . . ." 28 U.S.C. $\S 1291$ (1970).

3. 480 F.2d 1295 (8th Cir. 1973).

4. "The Supreme Court and all courts established by Act of Congress may issue all writs necessary or appropriate in aid of their respective jurisdictions and agreeable to the usages and principles of law." 28 U.S.C. $\$ 1651$ (a) (1970).

5. 480 F.2d at 1297.

6. Restatement $I$ of Torts defines interference with privacy in the following manner: "A person who unreasonably and seriously interferes with another's interest in not having his affairs known to others or his likeness exhibited to the public is liable to the other." RESTATEMENT OF TORTS $\$ 867$ (1939). Plaintiff's invasion of privacy claim was predicated upon both "false light" and "disclosure of private facts" theories. 480 F.2d at 1297. "False light" refers to the publication of material which portrays the individual to the public in a misleading fashion. An example of "false light" would be the publication of a person's photograph adjacent an article which had nothing to do with that person. "Disclosure of private facts" concerns objectionable publication of private infornation about the plaintiff. A well-known example of this would be the disclosure that a respectable woman had, years before, been a prostitute. W. Prosser, HandBook of the LaW of Torts 809 (4th ed. 1971). 
that the information was given to him in strict confidence as a newsman and that the revelation of the informant's name might subject the informant to reprisals from his superiors, the persons in the photograph, or both. Gialde inoved that Walsh be coinpelled to disclose his sources; Time, Inc. (Time) inoved for summary judgment on the merits. In a general order which imposed no penalties for failure to adhere to its terms, the court ordered Walsh to answer the plaintiff's questions and refused to grant summary judgment. Time appealed the court's order ${ }^{\tau}$ and, in addition, petitioned the appellate court to issue a writ of mandamus compelling the trial court to vacate its disclosure order and grant summary judgment in Time's favor. ${ }^{8}$

The Eighth Circuit, in an opinion written by Judge Van Oosterhout, dismissed the appeal for lack of jurisdiction, relying primarily on the final judgment rule; it also dismissed the petition for writ of mandamus. Judge Heaney dissented from the demal of mandamus. Unlike the majority, he declared that newsmen possess a qualified privilege to refuse to reveal their sources in civil suits; further, he found that such a privilege could be protected only through immediate appellate review. Therefore, Judge Heaney felt that the issue should be decided at once by the court through the use of its inandamus jurisdiction. ${ }^{9}$

The final judgment rule provides that only final judgments which dispose of a case on its merits are appealable. ${ }^{10}$ This rule has been a basic element of the American legal system since the colomal period ${ }^{11}$ and was explicitly adopted by Congress in the Judiciary Act of $1789.1^{12}$ While there are several statutory exceptions to the rule, ${ }^{13}$ 1302-04.

7. The appeal was made pursuant to 28 U.S.C. $\S 1291$ (1970). 480 F.2d at

8. This petition for a writ of mandamus was made pursuant to 28 U.S.C. $\S 1651$ (1970). 480 F.2d at 1302-04.

9. 480 F.2d at 1302-04.

10. See, e.g., Bohms v. Gardner, 381 F.2d 283, 285 (8th Cir. 1967), cert. denied, 390 U.S. 964 (1968), where the court stated the rule as follows: "Our jurisdiction of appeals from federal district courts is based upon the statutory concept of finality. ..." The court also stated that finality in this sense refers to the point at which the litigation lias reached an end and no more remains to be done by the court except to execute judgment. Id.

11. Crick, The Final Judgment as a Basis for Appeal, 41 YALE L.J. 539, 548-52 (1931). For general discussions of the final judgment rule, see 3A W. BarRoN \& A. Holtzoff, Federal Practice and Procedure \& 1552 (Wright ed. 1960); 9 J. Moore \& B. WARD, MoOre's Federal Practice fiी 110.06-.13 (2d ed. 1973).

12. Judiciary Act of 1789 , ch. $20, \S \S 21,22,25,1$ Stat. 73, 83-87. Section 21 deals with the need for finality in admiralty. Section 22 requires that only final decisions be appealed to a circuit court. Likewise, section 25 makes a final judgment 
a final judgment is still required for appellate review in the vast inajority of cases. ${ }^{14}$ Such consistent deference to the final judgment rule is not explained merely as a stubborn judicial adherence to an antiquated rule; instead, it reflects the courts' perception of a strong congressional policy aimed at eliminating piecemeal litigation and delay while conserving judicial energy. ${ }^{15}$ There are other significant consid-

from the highest court in a state mandatory before a state decision can be appealed to the Supreme Court.

13. There are four principal statutory exceptions to the final judgment rule in federal courts: (1) the power of federal appellate courts to issue extraordinary writs under 28 U.S.C. $\$ 1651$ (1970); (2) the grant of jurisdiction by 28 U.S.C. $\$ 1292$ (a) (1970) to the courts of appeals to entertain appeals of interlocutory orders of district courts pertaining to the issuance of injunctions, interlocutory orders appointing receivers or refusing to wind up receiverships, interlocutory decrees deternining rights and liabilities of parties to admiralty cases, and judgments in civil actions for patent infringement which are final except for accounting; (3) the discretion given a trial judge by 28 U.S.C. $\S 1292(b)$ (1970) to certify issues for immediate review upon acceptance by the court of appeals; and (4) the discretion given a trial judge by Federal Rule of Civil Procedure 54(b) to direct entry of final judgment of one or more claims in a multi-claim action when not all claims have come to final judgment.

In Gialde, Time asked for immediate review of the trial court's refusal to certify the case for interlocutory appeal under 28 U.S.C. $\$ 1292(b)$ (1970). The relevant portion of section $1292(\mathrm{~b})$ reads as follows:

(b) When a district judge, in making in a civil action an order not otherwise appealable under this section, shall be of the opinion that such order involves a controlling question of law as to which there is substantial ground for difference of opinion and that an immediate appeal from the order may materially advance the ultimate termination of the litigation, he shall so state in writing in such order. The Court of Appeals may thereupon, in its discretion, pernit an appeal to be taken from such order. . . .

Clearly any certification of an issue under section $1292(\mathrm{~b})$ is at the discretion of the trial judge. See, e.g., Dearbom Stone Co. v. Farmer's Cooperative Gas \& Oil Co., 304 F.2d 273 (8th Cir. 1962). The Gialde court dismissed the appeal because, not having been certified by the trial judge under section 1292(b), it did not fall within the only applicable exception to the final judgment rule; therefore the court lacked jurisdiction. 480 F.2d at 1300-01.

14. See, e.g., Baltimore Contractors, Inc. v. Bodinger, 348 U.S. 176, 178-79 (1955); Catlin v. United States, 324 U.S. 229, 233 (1945); Pauls v. Secretary of Air Force, 457 F.2d 294, 297 (1st Cir. 1972); Dalto v. Richardson, 434 F.2d 1018, 1019 (2d Cir. 1970), cert. denied, 401 U.S. 979 (1971); United Transp. Union v. Illinois Cent. R.R., 433 F.2d 566 (7th Cir. 1970); Transportation-Communication Div.-Bhd. of Ry. Employees v. St. Louis-San Francisco Ry., 419 F.2d 933, 935 (8th Cir. 1969), cert. denied, 400 U.S. 818 (1970); Bohms v. Gardner, 381 F.2d 283, 285 (8th Cir. 1967).

15. See Baltimore Contractors, Inc. v. Bodinger, 348 U.S. 176, 178 (1955); Catlin v. United States, 324 U.S. 229, 233-34 (1945); McLish v. Roff, 141 U.S. 661, 665-66 (1891). This congressional policy is inferred by the Supreme Court from the history of legislation which traditionally has allowed appeal only from final judgments. The Supreme Court in McLish stated: "From the very foundation of our judicial system the object and pohicy of the acts of Congress in relation to appeals . . . have been to save the expense and delays of repeated appeals in the same suit, and to have the whole case and every matter in controversy in it decided in a single appeal." 141 U.S. at 665-66 (citation omitted). 
erations, however, which should compete with these goals for judicial attention. ${ }^{18}$ Perhaps the most important of these is the "danger of ... den[ying] justice through delay."17 The possibihty should be recognized that justice may be thwarted by postponing review of a nonfinal order until after final judgment has been reached, when it may be too late for any viable rehef. Due to the recognition of this danger, the courts do not blindly follow the final judgnent rule; rather, courts have developed several devices for avoiding the rule when its application would be mappropriate. ${ }^{18}$

One of the most important escape hatches from the final judgnient rule is judicial manipulation of the definition of a final judgenent. Section 1291 of the Judiciary and Judicial Procedure Act, which currently embodies the federal version of the final judgment rule, states that the "court of appeal shall have jurisdiction of appeals from all final decisions of the district courts of the Umited States. . .."10 It does not define "final decisions." While Justice Rutledge once wrote that a final decision is one which "leaves nothing for the court to do but execute the judgment,"20 Justice Black thought that the words "[did] not necessarily mean the last order possible to be made in a a case." 21 In view of this judicial vacillation as to what constitutes a final judgment, the courts have been able, with the use of a practical interpretation of finality, to allow immediate appellate review of technically "nonfinal" orders in instances where the postponement of such review would result in great injustice. An interlocutory order removing parties from an ongoing action, ${ }^{22}$ the denial of a motion that a plaintiff be required to post security pursuant to state law in a derivative action, ${ }^{23}$ and the demal of a motion to quash a subpoena duces tecum which would require a non-party to the action to divulge trade

16. For a discussion of the policy behind the final judgment rule, see $9 \mathrm{~J}$. MOORE, supra note 11 , at $\Uparrow 110.07$.

17. Dickinson v. Petroleum Conversion Corp., 338 U.S. 507, 511 (1950).

18. Crick, supra note 11, at 553. Mr. Crick gives a detailed list of state statutory modifications of the rule. Id. at $\mathrm{nn}$. 64,66 . He feels that in addition to such statutory exceptions, the most effective means of circumventing the rule is through the use of extraordinary remedies-that is, writs of mandamus, prohibition, certiorari, and habeas corpus. Id. at 553-57. For federal statutory exceptions, see note 13 supra.

19. 28 U.S.C. $\$ 1291$ (1970) (emphasis added).

20. Catlin v. United States, 324 U.S. 229, 233 (1945).

21. Gillespie v. United States Steel Corp., 379 U.S. 148, 152 (1964). For a discussion of what constitutes a final judgment, see $9 \mathrm{~J}$. MOORE, supra note 11, at II $110.08(1)$.

22. Gillespie v. United States Steel Corp., 379 U.S. 148, 152-54 (1964).

23. Cohen v. Beneficial Indus. Loan Corp., 337 U.S. 541, 545-47 (1949). 
secrets ${ }^{24}$ have all been found sufficiently burdensome to justify ad hoc compromise of the final judgment rule. ${ }^{25}$

Another means of circumventing the final judgment rule is use of the extraordinary writ of mandamus. ${ }^{26}$ Under section 1651 of the Judiciary and Judicial Procedure Act, the federal courts ". . . may issue all writs necessary or appropriate in aid of their respective jurisdictions and agreeable to the usages and principles of law."27 Thus, a party aggrieved by a nonappealable interlocutory order may petition the appropriate appellate court for a writ of mandamus commanding the lower court to rescind its order. ${ }^{28}$ Whether mandainus should be granted or not is at the discretion of the appellate court, ${ }^{29}$ the question is not one of power, but of "whether in the light of all the circuinstances the case [is] an appropriate one for the exercise of that power." ${ }^{30}$ It should not be assumed, however, that federal courts have a hicense to use the writ at any time. As explained by Chief Justice Stone, the traditional use of the writ ". . . has been to confine an inferior court to the lawful exercise of its prescribed jurisdiction or to compel it to exercise its authority when it is its duty to do so."31 In other words, mandamus is usually granted in this context only to insure that a lower court accepts jurisdiction when it is required to do so, or to restrict a lower court to its proper area of jurisdiction. Mandamus is not considered a substitute for appeal, ${ }^{32}$ and courts hesitate to use it to circunvent the congressional pohicy against piecemeal appeals. ${ }^{33}$ As an extraordinary remedy, it should be "reserved for

24. Covey Oil Co. v. Continental Oil Co., 340 F.2d 993, 995-97 (10th Cir.), cert. denied, 380 U.S. 964 (1965).

25. Other examples of courts' willingness to ignore the final judgment rule include: Swift \& Co. Packers v. Compania Columbiana Del Carribe, S.A., 339 U.S. 684, 688-89 (1949) (appeal allowed of trial court's order dissolving an attachment in an admiralty case); Carr v. Monroe Mfg. Co., 401 F.2d 384, 386-87 (5th Cir. 1970), cert. denied, 400 U.S. 1000 (1971) (appeal allowed of trial court's order for production of documents over claim of governmental privilege).

26. Crick, supra note 11, at 554-55. For a detailed discussion of mandamus, see 9 J. MOORE, supra note 11, at Iी 110.26-.28.

27. 28 U.S.C. $\$ 1651$ (a) (1970).

28. The procedure for applying for the writ of mandamus is described in 9 J. MOORE, supra note 11 , at II 110.30 .

29. Schlagenhauf v. Holder, 379 U.S. 104, 111 n.8 (1964); La Buy v. Howes Leather Co., 352 U.S. 249, 255 (1957); Roche v. Evaporated Milk Ass'n, 319 U.S. 21, 25-26 (1943); Ex parte Peru, 318 U.S. 578, 584 (1943); Maryland v. Soper, 270 U.S. $9,29(1926)$.

30. Roche v. Evaporated Milk Ass'n, 319 U.S. 21, 25-26 (1943).

31. Id. at 26.

32. Ex parte Fahey, 332 U.S. 258, 260 (1947).

33. Roche v. Evaporated Milk Ass'n, 319 U.S. 21, 30 (1943). See note 15 supra and accompanying text. 
really extraordinary causes."34 The use of the writ may have been further restricted by the recent Supreme Court decision in Will $v$. United States. ${ }^{35}$ In that case, the defendant, who was charged with criminal tax evasion, successfully sought a court order compelling the government to reveal information concerning the identity of persons who had heard the defendant make a statement; to prevent this, the government obtained a writ of mandamus from the court of appeals. The Supreme Court reversed. Stressing the extraordinary nature of mandamus and the general need to postpone appeals until final judgment, the Court in dicta strongly discouraged the use of mandamus in any situation other than "exceptional circumstances amounting to a judicial 'usurpation of power." "36 Despite these warnings, mandamus can be and has been used in situations where there was no final decision and the issue did not involve the jurisdiction of the court. Such cases have involved "extraordinary situations" where substantial rights would be lost unless immediate review were permitted. Use of the writ for this purpose has been limited to cases involving such grave issues as federal-state relations, ${ }^{37}$ the preservation of the attorneyclient privilege, ${ }^{38}$ or the right to trial by jury. ${ }^{30}$ Although these cases did not involve questions of jurisdiction per se, the court in each found the issues so "extraordinary" that the participants were allowed to present their arguments for or against the issuance of mandamus. In this manner immediate review was permitted, thus insuring that

34. Ex parte Fahey, 332 U.S. 258, 260 (1947).

35. 389 U.S. 90 (1967).

36. Id. at 95 . It should be emphasized that Will was a criminal case "where the defendant is entitled to a speedy resolution of the charges against him." Id. at 97. This need for a speedy trial has caused the Supreme Court to look with disfavor upon interlocutory appeals in crimmal prosecutions. "[E]ncouragement of delay is fatal to the vindication of the criminal law." Cobbledick v. United States, 309 U.S. 323, 325 (1940). Further, the writ was issued without opinion, leaving the Supreme Court "in the dark with respect to the position of the Court of Appeals on issues crucial to an informed exercise of our power of review." 389 U.S. at 106. These factors make it uncertain whether Will should be read to indicate a Supreme Court policy making the writ less readily available. C. Wright, HANDBook on the LAW OF FEDERAL Courts 462 (2d ed. 1970).

37. See, e.g., Maryland v. Soper, 270 U.S. 9 (1926) (writ of mandamus proper where criminal case had been removed from proper state court to a United States district court, even though the federal court had jurisdiction since removal was permitted by statute).

38. See, e.g., Harper \& Row Publishers, Inc. v. Decker, 423 F.2d 487 (7th Cir. 1970), aff'd by equally divided Court, 400 U.S. 348 (1971) (writ of mandamus proper where trial court allowed discovery of contents of memorandum prepared by attorney while in conference with his clients).

39. See, e.g., Beacon Theatres, Inc. v. Westover, 359 U.S. 500 (1959) (writ of mandamus proper where defendant was denied a jury trial). 
precious rights which could not survive the wait for final judgment would not be irretrievably lost through error at the trial court level. ${ }^{40}$

Traditionally, it has been quite difficult to obtain immediate review of a discovery order, as Time attenpted to do in Gialde. ${ }^{41}$ It is well established that the scope of discovery is within the discretion of the trial judge ${ }^{42}$ and that orders compelling or denying discovery are interlocutory rather than final. ${ }^{43}$ Since such orders are not final, they almost never are appealable. ${ }^{44}$ Further, mandainus is not norinally available, since discovery orders do not usually present "extraordinary questions." 45 The only choices normally available to a dissatisfied party are to comply with the discovery order and appeal after final judgment, by which time the question will probably be inoot, or to ignore the order, thus risking a contempt citation which may then be appealed. ${ }^{48}$ While this latter alternative does provide an ave-

40. See the discussion of the court in Harper \& Row Publishers, Inc. v. Decker, 423 F.2d 487, 492 (7th Cir. 1970). "[B]ecause maintenance of the attorney-client privilege up to its proper limits has substantial importance to the administration of justice, and because an appeal after disclosure of privileged information is an inadequate remedy, the extraordinary remedy of mandamus is appropriate."

41. For a detailed discussion of appellate review of discovery orders, see $4 \mathrm{~J}$. MOORE, supra note 11 , at $\llbracket 26.83$.

42. See, e.g., Borden Co. v. Sylk, 410 F.2d 843, 845 (3d Cir. 1969); Chemical \& Indus. Corp. v. Druffel, 301 F.2d 126, 129 (6th Cir. 1962); Pennsylvania R.R. v. Kirkpatrick, 203 F.2d 149, 150 (3d Cir. 1953). The federal rules give wide scope to discovery.

Parties may obtain discovery regarding any matter, not privileged, which is relevant to the subject matter involved in the pending action, whether it relates to the claim or defense of any other party. . . . It is not ground for objection. that the information sought will be inadmissible at the trial if the information sought appears reasonably calculated to lead to the discovery of admissible evidence. FED. R. CIV. P. 26(b)(1).

For a discussion of the scope of discovery, see $4 \mathrm{~J}$. Moore, supra note 11, at $\Uparrow 26.55$.

43. See, e.g., Cobbledick v. United States, 309 U.S. 323, 327-28 (1940); Alexander v. United States, 201 U.S. 117, 122 (1906); Baker v. F.F. Inv. Co., 470 F.2d 778, n.3 (2d Cir. 1972); Borden Co. v. Sylk, 410 F.2d 843, 845 (3d Cir. 1969); Apex Hosiery Co. v. Leaden, 102 F.2d 702 (3d Cir. 1939). See also 2A W. BarRoN \& A. HOLTZOFF, supra note 11, at $\$ 657 ; 4 \mathrm{~J}$. MOORE, supra note 11, at $\uparrow 26.83$ [3].

44. Pauls v. Secretary of Air Force, 457 F.2d 294 (1st Cir. 1972); Carolina Power \& Light Co. v. Jernigan, 222 F.2d 951 (4th Cir.), cert. denied, 350 U.S. 837 (1955); Dille v. Carter Oil Co., 174 F.2d 318 (10th Cir.), cert. denied, 338 U.S. 850 (1949); Bowles v. Commercial Cas. Ins. Co., 107 F.2d 169 (4th Cir. 1939).

45. Chemical \& Indus. Corp. v. Druffel, 301 F.2d 126 (6th Cir. 1962); Pennsylvania R.R. v. Kirkpatrick, 203 F.2d 149 (3d Cir. 1953); Bank Line Ltd. v. United States, 163 F.2d 133 (2d Cir. 1947). For a discussion of the use of mandamus in regard to discovery orders, see $4 \mathrm{~J}$. MooRE, supra note 11, at $\Uparrow 26.83$ [9.-3].

46. See, e.g., United States v. Ryan, 402 U.S. 530 (1971); Cobbledick v. United States, 309 U.S. 323 (1940); Alexander v. United States, 201 U.S. 117 (1906); Childs v. Kaplan, 467 F.2d 628 (8th Cir. 1972); United States v. Anderson, 464 F.2d 1390 (D.C. Cir. 1972). 
nue for immediate review of the discovery order, ${ }^{47}$ it will sometimes fail to protect the aggrieved party. The dangers involved in electing this alternative are great, including possible imprisonment. Often, rather than accept the risk of punishment for contempt, a party will simply comply with the order, thus abandoming his claim that the order is improper without a full adjudication of the merits of that claim. Reliance on contempt proceedings as the only avenue for immediate review is particularly inadequate when discovery is compelled over a claim of privilege-for the social policy behind the privilege is thwarted if the danger of punishment for contempt leads to widespread "voluntary" relinquishment of the privilege. ${ }^{48}$ In another context, the Fifth Circuit has stated in United States $v$. Wood that ". . . an order, otherwise nonappealable, determining substantial rights of the parties which will be irretrievably lost if review is delayed until final judgment may be appealed immediately under section 1291."40 Unfortunately, the Fifth Circuit did not formulate criteria for deciding whether a "substantial right" is at issue, and the needed definition of "substantial right" is generally lacking in cases dealing with the point. ${ }^{60}$ Despite this lack of clear guidelines, courts have at times allowed immediate appeal of discovery orders when what the courts considered to be important rights or privileges were asserted $; 11 \mathrm{~m}$ like fashion, courts have occasionally granted mandamus im such situations. ${ }^{52}$

47. A contempt citation is a final order. Thus, once a contempt citation is given, it can be appealed immediately. During this appeal, arguments may be presented on the merits of the claim that the discovery order was improper.

48. See Development in the Law-Discovery, 74 HARv. L. REv. 940, 994 (1960).

49. United States v. Wood, 295 F.2d 772, 778 (5th Cir. 1961), cert. denied, 369 U.S. 850 (1962). In the Wood case, the federal government sought an injunction restraining the state prosecution of a Negro civil rights worker who had encouraged voter registration in Mississippi. The United States asked for and was granted un appeal from the trial court's denial of this injunction. While the case did not involve a discovery order, it is analogous to the situation in which discovery is ordered over a claim of privilege, in that both situations entail a right which will be lost if the final judgment rule blocks appeal.

50. In determining what is or is not a substantial right, it is perhaps most productive to examme the rights which have been so designated in previous cases. In Wood, for example, the substantial right referred to is the right to vote. $295 \mathrm{~F} .2 \mathrm{~d}$ at 777. For cases which illustrate rights which were considered sufficiently inportant to justify immediate review of discovery orders, see notes 51 \& 52 infra.

51. See, e.g., Fears v. Burris Mfg. Co., 436 F.2d 1357 (5th Cir. 1971) (governmental privilege not to produce confidential documents); Carr v. Monroe Mfg. Co., 431 F.2d 384 (5th Cir. 1970) (similar governmental privilege); Carter Products, Inc. v. Eversharp, Inc., 360 F.2d 868 (7th Cir. 1966) (subpoena quashed which sought information vital to defense); Covey Oil Co. v. Continental Oil Co., 340 F.2d 993 (10th Cir. 1965) (discovery order would reveal trade secrets).

52. See, e.g., Schlagenhauf v. Holder, 379 U.S. 104 (1964) (mandamus justified 
Gialde not only involved the question of whether a discovery order should be subject to immediate review if it allegedly violates a privilege, but also whether any privilege could legitimately be raised in the case. The privilege asserted by Time was that of newsmen to refuse to reveal their sources in order to protect both their ability as journalists to gather news and the related right of the public ${ }^{53}$ at large to receive a maximum amount of information. It lias been argued $^{54}$ that both these rights are guaranteed by the first amendment. ${ }^{55}$ While a number of recent legal articles have supported a journalist's privilege, ${ }^{56}$ the weight of judicial authority has refused to recognize its existence. ${ }^{57}$ The debate seemed to coine to a close when the

where trial court orders extensive medical examinations over petitioner's objection); Pfizer, Inc. v. Lord, 456 F.2d 545 (8th Cir. 1972) (Inandamus justified where attorneyclient privilege asserted); Harper \& Row Publishers, Inc. v. Decker, 423 F.2d 487 (7th Cir. 1970) (mandamus justified where attorney-client privilege asserted); United States v. Henuphill, 369 F.2d 539 (4th Cir. 1966) (nuandamus justified where court orders Secretary of Labor to reveal names of anonymous complainants); cf. Metros v. United States Dist. Ct., 441 F.2d 313 (10th Cir. 1971) (writ of prohibition proper where court orders police officers to reveal name of informant). Prohibition, used in Metros, is an extraordinary writ, as is mandamus. As its name implies, it is used by a superior court to prohibit a lower court from taking certain actions. "A prohibition is a writ . . . directed to the judge and parties of a suit in any inferior court, commanding them to cease from prosecution thereof, upon a suggestion that either the cause originally, or some collateral matter arising therein, does not belong to that jurisdiction, but to the cognizance of some other court." $3 \mathrm{~W}$. BLACKSTONE, COAFMENTARIES $* 112$.

53. Litigants do not generally have standing to raise the rights of third parties. See, e.g., Tileston v. Ullman, 318 U.S. 44 (1943). While a newsnan raises the rights of the public when he refuses to reveal his sources, two factors militate towards allowance of the assertion of third party rights in this situation: first, the public has no way of raising these rights except through sucl third party assertion; second, the Suprenie Court has relaxed, in first anendment cases, the rule which forbids the assertion of rights of third parties. See note 77 infra.

54. See, e.g., Comment, Constitutional Protection for the Newsman's Work Product, 6 Harv. CTv. Rights-Civ. LIB. L. Rev. 119, 124-25 (1970); Note, Reporters and Their Sources: The Constitutional Right to a Confidential Relationship, 80 YALE L.J. 317, 325-38 (1970).

55. "Congress shall make no law . . . abridging the freedon of speech, or of the press. . . ." U.S. Const. amend. I.

56. See, e.g., Comment, The Newsman's Privilege: Government Investigations, Criminal Prosecutions and Private Litigation, 58 CALIF. L. REv. 1198 (1970); Note The Right of the Press to Gather Information, 71 Colum. L. Rev. 838 (1971); Note, Reporters and Their Sources, supra note 54.

57. See, e.g., Garland v. Torre, 259 F.2d 545 (2d Cir.), cert. denied, 358 U.S. 910 (1958); Rosenberg v. Carroll, 99 F. Supp. 629 (S.D.N.Y. 1951); In re Pappas, 358 Mass. 604, 266 N.E.2d 297 (1971), affd sub nom. Branzburg v. Hayes, 408 U.S. 665 (1972); Branzburg v. Pound, 461 S.W.2d 345 (Ky. 1970), aff'd sub nom. Branzburg v. Hayes, 408 U.S. 665 (1972); In re Taylor, 412 Pa. 32, 193 A.2d 181 (1963) (journalist's privilege held a statutory rather than constitutional right); In re Goodfader's 
Supreme Court, with four Justices dissenting, declined to recognize a reporter's privilege to refuse to reveal sources to a grand jury in Branzburg v. Hayes. ${ }^{58}$ Whether or not Branzburg was correctly decided, it dealt with a grand jury investigation of a criminal case where the need for full disclosure of sources is much more compelling than in the setting of civil litigation. ${ }^{59}$ The case does not deal with the power of a private citizen to force disclosure of sources by bringing a hibel suit and then obtaining a pre-trial discovery order. This situation occurred in $\mathrm{Cer}$ vantes v. Time, Inc., ${ }^{60}$ where the mayor of St. Louis had sued Time for libel and then asked for disclosure of Time's sources. When the trial court granted Time's motion for suminary judgment before allowing discovery, Cervantes appealed. The Eighth Circuit ruled that in such situations the trial court should force disclosure only if the

Appeal, 45 Hawaii 317, 367 P.2d 472 (1961). But see Caldwell v. United States, 434 F.2d 1081 (9th Cir. 1970), rev'd sub nom. Branzburg v. Hayes, 408 U.S. 665 (1972); In re Grand Jury Witnesses, 322 F. Supp. 573 (N.D. Cal. 1970); State v. Knops, 49 Wis. 2d 647, 183 N.W.2d 93 (1971).

58. 408 U.S. 665 (1972). The opinion of the Court in Branzburg applied to appeals of three well-publicized cases: Caldwell v. United States, 434 F.2d 1081 (9th Cir. 1970) (existence of a qualified journalist's privilege recognized by the Ninth Circuit); In re Pappas, 358 Mass. 604, 266 N.E.2d 297 (1971) (existence of journalist's privilege denied by the Supreme Judicial Court of Massachusetts); Branzburg v. Pound, 461 S.W.2d 345 (Ky. 1970) (existence of journalist's privilege denied by the Court of Appeals of Kentucky).

59. The focal point of the Branzburg decision is the fact that the request for disclosure came from a grand jury investigating a criminal matter. "The sole issue before us is the obligation of reporters to respond to grand jury subpoenas as other citizens do and to answer questions relevant to an investigation into the commission of crime." 408 U.S. at 682 (1972). The grand jury's need for access to all relevant information is often stressed. For example, Justice White, speaking for the majority, wrote:

Because [the grand jury's] task is to inquire into the existence of possible criminal conduct and to return only well-founded indictments, its investigative powers are necessarily broad .... Although the powers of the grand jury are not unlimited and are subject to the supervision of a judge, the longstanding principle that "the public ... has a right to every man's evidence," except for those persons protected by a constitutional, common-law, or statutory privilege, is particularly applicable to grand jury proceedings.

Id. at 688 (citations omitted).

Further, Justice White considered it important that the case involved criminal activity: "II]t is obvious that agreeinents to conceal information relevant to cornmission of crime have very little to recommend them from the standpoint of public policy." Id. at 696. Finally, an assumption which underlies the decision is that grand jury investigations are made in good faith: "[G]rand jury investigations if instituted or conducted other than in good faith, would pose wholly different issues for resolution under the First Amendment. . . . We do not expect courts will forget that grand juries must operate within the limits of the First Amendment as well as the Fifth." $I d$. at 707-08. The opinion does not reach the question of the existence of a journalist's privilege in civil actions.

60. 464 F.2d 986 (8th Cir. 1972), cert. denied, 409 U.S. 1125 (1973). 
movant first shows that such information will help show evidence of actual malice, a necessary element of libel which as a matter of law must be proved in a large proportion of libel cases. ${ }^{61}$ The court thus recognized what Judge Heaney in Gialde called "a qualified journalist privilege under the First Amendunent." ${ }^{2}$ Less than a year after the Branzburg decision, the Supreme Court denied certiorari in Cervantes, $^{63}$ possibly indicating that the Court in Branzburg did not intend to close the door to the recognition of a journalist's privilege in civil litigation. It should be noted that, while a recognition of a newsman's privilege would have greatly enhanced defendant Time's chance of obtaining immediate review of the controverted court order in Gialde, such recognition was not absolutely essential to Time's case. The court could have held that no "journalist's privilege" exists per se, and still have allowed immediate review under the inore general precedents allowing immediate review by appeal or mandamus when substantial rights or privileges, such as the first amendment rights of Time and the public as well as the personal safety of reporter Walsh's informant, could be irretrievably lost by judicial error at the trial level. ${ }^{\text {s4 }}$

In meeting the problems presented by Gialde, the court emphasized the fact that the discovery order had applied no sanctions to the reticent reporter. It further noted the general rule that such pre-

61. Id. at 993-94. "Actual malice" in the bibel setting has come to mean publication with "knowledge of falsehood" or "reckless disregard for the truth." Rosenbloom v. Metromedia, Inc., 403 U.S. 29 (1971); St. Amant v. Thompson, 390 U.S. 727 (1968); New York Times Co. v. Sullivan, 376 U.S. 254 (1964). New York Times v. Sullivan held that actual makice is an element of libel when the suit is "brought by public officials against critics of their official conduct." 376 U.S. at 283. Since that decision, the requirement of proof of actual malice has been given an increasingly more general application. See W. Prosser, supra note 6 , at $\$ 118$. The decision in Rosenbloom extended the requirement of actual malice to cases involving public interest. "It is clear that there has emerged from our cases decided since New York Times v. Sullivan the concept that the First Amendment's impact upon state libel laws derives not so much from whether the plaintiff is a 'public official,' 'public figure,' or 'private individual,' as it derives from the question whether the allegedly defamatory publication concerns a matter of public or general interest." 403 U.S. at 44. Arguably, a matter is of "public interest" whenever a magazine or newspaper chooses to publicize it. "To a very great extent the press, with its experience or instinct as to what its readers want, has succeeded in making its own definition of news. . . " See W. Prosser, supra note 6 , at 824 . In a case such as Gialde, which clearly involves a matter of public interest, the plaintiff must lose as a matter of law if he is unable to prove actual malice.

The requirement of actual malice has been extended to cases involving invasion of privacy. Time, Inc. v. Hill, 385 U.S. 374 (1967).

62. Gialde v. Time, Inc., 480 F.2d 1285, 1302 (8th Cir. 1973).

63. Cervantes v. Time, Inc., 409 U.S. 1125 (1973).

64. See note 49 supra and accompanying text. 
liminary orders are not final orders under section 1291. In justifying application of the final judgment rule to preclude interlocutory relief, the court cited the recent Supreme Court decision in United States v. $R y a n^{65}$ for the proposition that a party who refuses to comply with a discovery order will have adequate opportunity to assert his objections thereto before he inay be held in conteinpt for noncoinpliance. ${ }^{66}$ The court did not agree with Tine's argument that immediate appeal froin discovery orders should be allowed. In concluding that it lacked appellate jurisdiction to review a discovery order in an ongoing case, ${ }^{, 7}$ the inajority focused on the utility of the fimal judgment rule as a check on premature appeals which tend to "delay disposition of the case" and "make the cost of litigation prohibitive for persons of modest means." ${ }^{8}$ In contrast to its thoughtful analysis of the policy justifications for the final judgment rule, the majority failed to discuss the first amendinent issues and the claimed journalist's privilege which the case seeined squarely to present.

The court also dismissed defendant's petition for inandamus. Citing Will $v$. United States ${ }^{69}$ as authority for the limited function of mandamus, the court declared that the petition for mandamus added nothing to the argument in the primary appeal and reprimanded the defendant for "atteinpting to use the writ as a substitute for an interlocutory appeal."70 Applying a stringent standard which it did not articulate, the court held that Time had failed "to show [the] extraordinary circumstances whiclı would entitle it to inandamus."

The decision in Gialde prompted a strong dissent from Judge Heaney. His emphasis was far different from that of the majority.

65. 402 U.S. 530 (1971).

66. 480 F.2d at 1300 .

67. The court also held that it lacked appellate jurisdiction to review the denial of Time's motion for summary judgment. In its attempted appeal from the denial of summary judgment, defendant Time had argued that in a libel action a defendant has a right to obtain immediate review of such denial. Washington Post Co. v. Keogh, 365 F.2d 965 (D.C. Cir. 1966), cert. denied, 385 U.S. 1011 (1967), stresses the inportant function that summary judgment cau play in assuring that such suits are not brought to inhibit first anendment rights. This language suggests a constitutional right to summary judgment in bibel actions if the plaintiff cannot show evidence of actual malice, since actual malice is a necessary element of libel. See id. at 968. However, the court in Gialde found the denial of summary judgment in this libel action to be a nonfinal, nonappealable order. "Defendant has cited no case which supports its view that an order denying summary judgment is appealable. We have found no such case." 480 F.2d at 1299.

68. 480 F.2d at 1301 .

69. 389 U.S. 90 (1970).

70. 480 F.2d at 1302 .

71. Id. 
He began his argument by recognizing a "qualified journalist privilege under the First Amendment." ${ }^{22}$ He then contended that this privilege allows journalists to refuse to disclose their news sources in libel actions unless the plaintiff clearly shows that such disclosure would lead to evidence of actual malice. Citing cases in which the invocation of a privilege in the face of a discovery order has been lield to justify either immediate appeal or mandanus, ${ }^{73}$ he rejected the notion that review of a contempt citation is a viable alternative to immediate review of the discovery order itself. Judge Heaney found Time's case for mandamus even more compelling than that involved in Pfizer, Inc. $v$. Lord ${ }^{74}$ in which the Eighth Circuit granted immediate review of a discovery order which would have violated the attorney-client privilege. In Gialde, not only would disclosure of the informant's name constitute an irreversible act, it would impinge upon "interests protected by the First Amendment which deserved permanent protection."

Gialde v. Time, Inc. reveals the competing principles at work in any attempted appeal of a pre-trial order directing a journahist to reveal his sources. On the one hand is the final judgment rule and the pragmatic considerations upon which it rests: the conservation of judicial time and energy; the policy against piecemeal appeals: and, perhaps to a lesser extent, concern about the additional financial burden of litigation which extra appeals place on the sincere plaintiff of modest means. On the other hand are the first annendment rights which would almost certainly be "chilled" by mass disclosure of news sources. ${ }^{76}$ Faced with this formidable dilemma, lowever, the court

72. Id.

73. Bristol-Meyers Co. v. Lord, Nos. 73-1284, 73-1285 (8th Cir. May 31, 1973); Pfizer, Inc. v. Lord, 456 F.2d 545 (8th Cir. 1972); Fears v. Burris Mfg. Co., 436 F.2d 1357 (5th Cir. 1971); Carr v. Monroe Mfg. Co., 431 F.2d 384 (5th Cir. 1970); Harper \& Row Publishers, Inc. v. Decker, 423 F.2d 487 (7th Cir. 1970); United States v. Heniphill, 369 F.2d 539 (4th Cir. 1966); Covey Oil Co. v. Continental Oil Co., 340 F.2d 993 (10th Cir. 1965).

74. 456 F.2d 545, 548 (8th Cir. 1972).

75. 480 F.2d at 1304. Judge Heaney wrote: "[A]ppeal after disclosure would not be an adequate remedy to protect the asserted privilege. Disclosure of an informant's name is an irreversible act. Once such disclosure occurs, any subsequent appeal is futile, and the defendant in effect loses the opportunity to present this Court its assertion that the disclosure violates those First Amendment rights which we recognized in Cervantes." Id. at 1303.

76. The reality of the danger that first amendment rights can be "chilled" by libel actions or even by the threat that such actions may be brought has been explicitly recognized by the Suprene Court. See Rosenbloon v. Metromedia, Inc., 403 U.S. 29, 52-53 (1971); New York Times Co. v. Sullivan, 376 U.S. 254, 279 (1964); cf. Time, Inc. v. Hill, 385 U.S. 374, 388-89 (1967) (invasion of privacy). The Circuit Court of Appeals for the District of Columbia recognized this danger in 
chose to ignore the question of first amendment rights and privileges and treat the order as a routine discovery order. ${ }^{77}$ Once this decision had been made, it was mevitable that jurisdiction would be demed, since nothing remained to offset the imperatives of the final judgment rule. The result of this preoccupation with the pragmatic foundations of the rule was a disappointing decision which too readily dismissed what seemed to be valid claims to first amendinent protection. ${ }^{78}$ In noting that the defendant could raise these issues on appeal from fimal judgment, the court ignored the essence of the first amendment argument-that only immediate relief would protect Walsh and the public in the exercise of their first amendment rights. More specifically, the Gialde court should have made a determmation as to whether the challenged discovery order adversely affected any "substantial rights of the parties which [would] be irreparably lost if review [were] delayed until final judgment." 79 This in turn would have forced the court to consider the existence vel non of a claimed newsman's privilege assertable agaimst civil discovery. In cases like Gialde, where the potentially indiscriminate use of discovery could impose real restraints upon freedom of the press and the ability of the media to obtain information by shutting off sources, the court should at least acknowledge the first amendment problems.

Washington Post Co. v. Keogh, 365 F.2d 965 (D.C. Cir. 1966), where it stated: "One of the purposes of the Time principle ... is to prevent persons from being discouraged in the full and free exercise of their First Amendment rights . . . . Unless persons, including newspapers, desiring to exercise their First Amendment rights are assured freedom from the harassment of lawsuits, they will tend to become selfcensors. And to this extent debate on public issues and the conduct of public officials will become less uninhibited, less robust, and less wide open, for self-censorship affecting the whole public is "hardly less virulent for being privately administered." " Id. at 968 .

77. In overlooking the first amendment issues presented in the case, the majority ignored a traditional emphasis placed on first amendment rights by the Supreme Court. This emphasis has caused the Court in the past to relax its normal rule that parties cannot raise the rights of third persons, see, e.g., Freedinan v. Maryland, 380 U.S. 51, 56 (1965) and Thornhill v. Alabama, 310 U.S. 88, 97 (1940); to strike down overly broad legislation in the first amendment area, see, e.g., NAACP v. Alabama ex rel. Flowers, 377 U.S. 288, 307 (1964) and NAACP v. Button, 371 U.S. 415, 433 (1963); and to gnard against the possible "chilling effect" upon first amendment rights by governmental or private action, see, e.g., Rosenbloom v. Metromedia, Inc., 403 U.S. 29, $52-53$ (1971); Dombrowski v. Pfister, 380 U.S. 479, 487 (1965); New York Times Co. v. Sullivan, 376 U.S. 254, 279 (1964); NAACP v. Button, 371 U.S. 415, 433 (1963).

78. While the majority refused to discuss the first amendment issues, it noted that Time's attorneys had presented an excellent brief on the subject and stressed that the decision expressed no view on the merits of the case. $480 \mathrm{~F} .2 \mathrm{~d}$ at 1301-02.

79. United States v. Wood, 295 F.2d 772, 778 (5th Cir. 1961). See note 49 supra and accompanying text. 
Three additional factors present in Gialde were not adequately addressed by the court and might have altered the result had they been fully considered. (1) This decision does not apply to all discovery orders; rather, it applies only to that narrow, specific element of discovery concerning the forced disclosure of newsinen's sources. Hence, a decision allowing immediate review in this case would not liave meant the destruction of the final judgment rule as applied to all discovery orders; instead, it would have created only a sinall exception to the rule. (2) Timie was not asking for an absolute privilege. It only desired that Gialde be required to show that the information sought was likely to produce evidence of actual malice. The recognition of such a limited privilege would not hinder plaintiffs in wellfounded libel actions. (3) Gialde involved only private civil actions for libel and invasion of privacy. Therefore, the recognition of a limited newsman's privilege in these actions would not have affected the law enforcement capability of local, state, and federal governinents.

By overlooking these elements of the case, the Eighth Circuit has produced an opimion which, if followed, could have an effect upon the media's ability to gather information commensurate with that of Branzburg. That case concerned only the need of a grand jury for disclosure of secret news sources in order to conduct a full investigation into criminal matters. ${ }^{80}$ The harm which may result if Gialde is followed is not so much that in some civil cases disclosure of sources may be coinpelled, for in some cases such a resnlt may be necessary to insure a just outcome of the litigation. Rather, the peril lies in the absence of a requirement that the plaintiff show that such information is necessary to his case or likely to produce evidence of malice. This opens up the possibility that any member of the public who becoines the subject of an uncomplimentary article may retaliate by forcing the publisher or his newsmen to reveal their secret sources. ${ }^{81}$ The only immediately apparent obstacles to such frivolous, retaliatory suits would be the difficulty of overcoming a motion for summary judg-

80. See note 59 supra.

81. There exists the possibility that the defendant in such a situation will be able to obtain a protective order limiting plaintiff's discovery. A trial court "may make any order which justice requires to protect a party or person from annoyance, embarrassinent, oppression or undue burden or expense." FED. R. Crv. P. 26(c). Such orders may either totally prohibit discovery or mold the scope of discovery to protect the movant. Id. It must be questioned, however, how much protection actually will be given by trial courts if, as in Gialde, there is no recognition of even a limited journalist's privilege.

For a general discussion of protective orders in discovery, see Developments in the Lav-Discovery, supra note 48 , at $980-85$. 
ment or the possibility of a countersuit for a malicious prosecution. ${ }^{82}$ The ability of private citizens to force disclosure of sources could significantly silence the anonymous informants who currently account for a large portion of the information disseminated by the media.

It may be hoped that the future will see a more viable compromise between the competing considerations of judicial economy and the press's ability to obtain information from anonymous sources than that represented by Gialde. One possible solution would be to recognize a limited journahist's privilege like that which the same circuit recognized in Cervantes: discovery of secret news sources in civil litigation would be allowed only after the plaintiff had made a showing that the evidence sought would demonstrate actual malice. The recognition of such a limited privilege would do much to protect first amendment rights; however, the possibility would remain that, through error by the trial court, such protection might be withheld. Since appeal after final judgment in this type of case provides madequatc relief, the possibility of obtaining a writ of mandainus should be left open to the journalist who is ordered to reveal his sources in a civil suit. In applying for the writ, a threshold burden should be on the movant to demonstrate before the court accepts jurisdiction that his right to the protection sought is "clear and indisputable"83 - that the trial court's denial of the privilege was clearly crroneous. $^{84}$ If this were

82. At common law, malicious prosecution was applicable only to criminal prosecutions. Today, the majority of American jurisdictions allow actions for malicious prosecution in civil cases as well, although a strong minority still limits actions for malicious prosecution to criminal cases. To establish malicious prosecution, the plaintiff must prove that suit was unjustifiably brought against him without probable cause and with malice. W. Prosser, supra note $6, \S 120$.

A more substantial protection against such bad-faith suits is the wide use of summary judgment in libel actions. Summary judgment is so often obtained in libel actions that some attorneys have asserted that a constitutional right to summary judgment exists in libel suits when the plaintiff cannot show actual malice. This argument has not been accepted by the courts. See note 67 supra. While a frequent use of summary judgment decreases the number of malicious libel suits that can be expected, it cannot provide full protection as long as summary judgment in such situations is not mandatory. It should be noted that summary judgment was denied in Gialde by the trial court and that immediate appeal was not allowed by the court of appeals; neither court made mention of the presence or absence of actual malice. 480 F.2d at 1297. Gialde itself shows that summary judgment at present does not provide a panacea for the first amendment problems involved in such cases.

83. United States v. Duell, 172 U.S. 576, 582 (1899); accord, Will v. United States, 389 U.S. 90, 96 (1967); Bankers Life \& Cas. Co. v. Holland, 346 U.S. 379, 384 (1953).

84. Such a threshold requirement need not be satisfied before an appellate court can accept jurisdiction of an appeal. In the federal courts, the only requirement for appeals allowed as of right is the filing of a notice of appeal with the district court. Upon the filing of this notice, the court of appeals automatically obtains jurisdiction of the case. See 9 J. MOORE, supra note 11, at III 203.03, 203.08. 
required, mandamus would not be available to provide automatic appeal of every trial court failure to recognize a journalist's privilege; this occasional use of the writ would not have the detrimental effect on judicial economy which frequent interlocutory appeals would have.

It is imperative that some resolution be found which will not swamp the courts with interlocutory appeals, will not deny essential discovery devices to serious litigants, and yet will not destroy the informationgathering capability of the inedia. Given the importance of the competing considerations involved-the final judgment rule and the potentially dangerous results of unchecked discovery-the question of the forced disclosure of journalists' sources in civil litigation cries out for immediate legislative action providing protection for the rights of newsmen and the public which are endangered in this setting. Until that day arrives, the courts should afford a shelter for these first amendinent rights by recognizing a journalist's privilege in civil suits and the concomitant right to immediate review of discovery orders which force the revelation of anonymous news sources. 